\title{
THE EFFECT OF EYE-FOOT COORDINATION, FLEXIBILITY OF THE LIMBS, BODY BALANCE AND SELF-CONFIDENCE TO THE ACCURACY OF THE FOOTBALL OF SEPAK TAKRAW
}

\author{
Jufrianis $^{1}$, Akbar ${ }^{2}$, James Tangkudung ${ }^{3}$ \\ Universitas Pahlawan Tuanku Tambusai ${ }^{1}$ \\ State University of Jakarta ${ }^{2}$ \\ State University of Jakarta ${ }^{3}$ \\ jufrianis@universitaspahlawan.ac.id ${ }^{1}$ \\ Akbaralwi85@gmail.com ${ }^{2}$ \\ Jamestangkudung.unj@unj.ac.id ${ }^{3}$
}

\begin{abstract}
The purpose of this study was to obtain the effect of eye-foot coordination, flexibility of the limbs, body balance and self-confidence to the accuracy of the football of sepak takraw. The research method used in this research is the type of quantitative research with causality study approach. Technical Analysis uses a path analysis approach. Total population The study population is 40 athletes, sampling technique with total sampling. The number of samples in this study are 40 athletes who follow the Center for Student Development and Training. the results of this study conclude: (1) foot-eye coordination can directly affect the accuracy of the football on sepak takraw of $6.94 \%$ (2) limb formation can directly affect the accuracy of the football's early takraw of 5.96\%, 3 ) the balance of the body can directly affect the initial accuracy of sepak takraw by 3.53\%, (4) Self-confidence can directly affect the accuracy of the footballing of sepak takraw by 4.38\%, (5) foot-eye coordination can affect direct self-confidence of $3.56 \%$, (6) limb formation can directly influence self-confidence of $2.54 \%$, (7) the balance of the body can directly affect self-confidence by $2.36 \%$.
\end{abstract}

Keywords: Foot-Coordination, Limb Formation, Body Balance, Self Confidence and Accuracy of Football Upper Sepak takraw.

Exercise is a way to get a healthy life. There are various sports, one of them sports games. As we know, there are many game sports, one of them is sepak takraw. Sepak takraw as a game that is dominated by feet that plays takraw balls on a field as large as badminton court and is competed between two teams facing each other with the number of players each 3 (three) people (Achmad Sofyan Hanif, 2015: 11). In the center is limited by a net, in the same game as a soccer game, which is used by the foot and all the limbs except the hand. The goal of the game takraw is to return the ball in such a way that it can fall in the field of the opponent or cause the opponent to make mistakes or violations, (Iyakrus, 2010: 1).

As a team sporting game, sepak takraw is played on a rectangular pitch with a flat surface, both indoors and outdoors, provided it is free of obstacles. This game starts with doing football (service) which is done by tilting towards the opponent's field, then the opposing player plays the ball using the foot or other body parts except the hand, with three touches both alternately and done by a player.

These sepaktakraw games desperately need high basic techniques such as Sepak Mula, Smes and Blocking, among these basic techniques one of the basic techniques that must be mastered to launch attacks in sepak takraw is martial arts. A sharp and accurate start in the game sepaktakraw is very dominant once to generate numbers. 
The start is a kick that is carried out by the team towards the opposing field as a way to start the game (Abdul Azizi Hakim, Sudarso, Arif Bulqini). Means originality is one kick in sepak takraw. Asepta Yoga mentions, early soccer is a technique to do the initial kick in a game sepak takraw. The play is played by Tekong in the initial circle after getting the pitch / throw from the bouncer (right / left sling) (Asep Yoga Permana). The start is done by the tekong towards the opponent, is a very important way of working because the numbers or points can be obtained directly by the team that does the football (service). To position the left apit, right apit and tekong while doing the start prefix can be seen in the following picture.

The role of a tekong is very important, because it is the position of the shaft for the right / left apit, being in the middle position of the game area itself makes this position should be able to make a good contribution for the team, directing the football in accordance with the weakness of the opponent. Tekong is usually a "brain" in a squad (Rick Engel). The beginnings of the sepak takraw game need to get enough attention, because football is the main capital if it can be used as well as possible, because it can directly generate points or numbers. Achmad Sofyan said, for that service should be made with various ways in order to ravage or deceive the opponent, especially about the target service that will be done (Achmad Sofyan Hanif).

Based on the height of the ball when kicked out by tekong in the first place, the football is divided into the bottom football that is the football that is done with the height of the ball when performing a lower kick of the shoulder, and the first football is that the football is done when the ball is higher from the shoulders (Abdul Azizi Hakim, Sudarso, Arif Bulqini). First the effort must be made to aim towards the opponent's weakness, so that it can disrupt the opponent's defense and the team that starts it can easily compile the next attack.

Foot-eye coordination is a very important physical component in performing the top football upon the perfection of the ball and the foot, because with excellent eye coordination of the ball with at the time of a hard and sharp start can be performed by an athlete with great accuracy well too. Subsequent Abstinence is one of the important physical components in doing the soccer on sepak takraw because of the flexibility of the limbs at the time of the top football in controlled by the flexibility of the leg movement so that athletes do not rigid football first. Furthermore, in starting the Balance of Balance is also indispensable when the foot rests on the body when the top kick is done and if the balance is good, then the football can be controlled properly in the correct state of body position. Therefore, after a number of physical components can influence the beginning of the game, the athlete's confidence is very supportive and influential as well, because if a good physical component starts with a good self-confidence, then the points and wins in the match will be achieved. It can be concluded that eye-foot coordination, limb flexibility, body balance and self-confidence play an important role in extending the leg range to the ball so that the results of the kick are accurate and precise. Therefore, in this study the authors take the title "The Effect of Foot-Eye coordination, Leg Leanness and Body Balance on Accuracy of Football Upper Sepak Takraw at the athletes of Education and Training of Students of DKI Jakarta Province".

\section{METHOD}

The research method used is a quantitative approach, a survey method with measurement and test techniques. While the analysis technique uses a path analysis approach (path analysis) that is research that will examine or that will analyze the relationship between research variables, and measure the direct and indirect influence between one variable on another variable (Sudaryono, Gaguk Margono, Wardani Rahayu).

This study involved four independent variables (exogenous) and one dependent variable (endogenous), the exogenous variables consisting of: balance, flexibility of the hip joint, and eye-foot coordination. Endogenous variables are the initial soccer skills of sepak takraw in male and female 
athletes in Riau Province Pekanbaru. The pattern of linkages between variables is shown in the following figure:

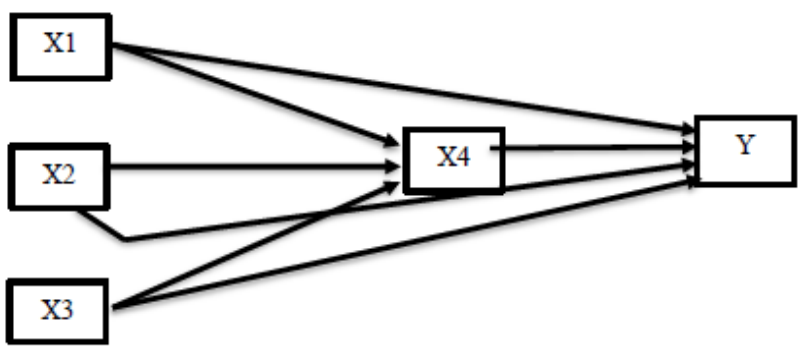

Figure 3.1. The constellations $\mathrm{X} 1, \mathrm{X} 2, \mathrm{X} 3$ and $\mathrm{X} 4$ Against $\mathrm{Y}$

Findings

Information :

$\mathrm{X} 1$ : Eye-Foot Coordination

X2: Limb Formation

X3: Body Balance

$\mathrm{X} 4$ : Confidence

Y: Accuracy Start Up Sepaktakraw

\section{Population and Sampling Techniques}

\section{Population}

The population is the whole subject of the study according to Suharisimi Arikunto. While Riduwan said the population is an object or subject that is in a region and meet certain conditions relating to research problems. This definition implies that the population is the whole individual who will be used as the object of research and the whole of the individual has at least one (homogeneous) characteristic.

As said homogeneous population riders are a source of data whose elements have the same nature so there is no need to question the amount quantitatively. So that in this study that was used as the research target population were all Jakarta Province Student Education and Training athletes consisting of 40 athletes.

\section{Sample}

The sample is a small number of groups drawn from the population environment (Agung Sunarmo and Syaifullah D.Sihombing). Whereas according to Hidayat Syah the sample is representative of the whole or of a larger group, presented for examination or as evidence of quality. Therefore the selected sample should be representative and in accordance with the research design.

Sampling is done using total sampling technique. The sample of research is athletes Education and Training Students of men and women in Jakarta Province amounted to 40 people. In order to truly obtain the value as a result of the research so that it can be generalized to the existing population, various observations that could influence the results of the study were carried out before the research sample must have the same (homogeneous) characteristics as:

a. Athletes Education and Training Students sepak takraw DKI Jakarta province son and daughter.

b. All athletes under study have attended various regional championships, as well as nationally.

\section{RESULTS AND DISCUSSION}

Based on the results of data analysis and hypothesis test above, the following will be discussed explanation for each of the conclusions obtained. 


\section{Direct Influence of Foot-Coordination (X1) to Accuracy of Football Upper Sepak takraw (Y)}

There is a significant effect of eye-foot coordination on the accuracy of the game's football on sepak takraw. after testing the hypothesis proved to be individually significant effect on the accuracy of the first football on sepak takraw game at athletes Student Education And Training Center Jakarta. The structural equation from the results of path analysis from eye-foot coordination to soccer accuracy at the beginning of the game sepak takraw is X2 $=0.347 \rho 21+0.982 \varepsilon 1$.

The influence of eye-foot coordination variables directly on the accuracy of the football from the game sepak takraw is $0.3472 \times 100 \%=0.0694$ or $6.94 \%$. From the description, it can be seen that the direct influence of eye-foot coordination variables on the initial accuracy of the remaining sepak takraw play is the influence of other variables apart from the eye-foot coordination variable. Other variables that may affect the initial accuracy of the sepak takraw game are exercise, biomotor and other physical conditions.

From the results of the description above we can see the results of research on the effect of eye-foot coordination on soccer accuracy from the game sepak takraw on Student Education And Training Center Jakarta athletes. This finding shows, that to improve the performance of sepak takraw athletes, an athlete must have good eye-foot coordination of course, where this variable has a direct influence in improving the achievement of Jakarta Student Education And Training Center athletes going forward.

\section{Direct Influence of Leg Formation (X2) on the Upper Accuracy of Sepak takraw (Y).}

There is a significant influence on the flexibility of the legs to the initial accuracy of the game Sepak takraw. after testing the hypothesis proved to be individually significant effect on the accuracy of the first football on sepak takraw game at athletes Student Education And Training Center DKI Jakarta. The structural equation from the results of path analysis from the leg's flexibility to soccer accuracy from the beginning of the game sepak takraw is X2 $=0.298 \rho 21+0.982 \varepsilon 1$.

The influence of the limb flexibility variables directly on the accuracy of the football from the game sepak takraw is $0.2982 \times 100 \%=0.0596$ or $5.96 \%$. From the description, it can be seen that the influence of the limb flexibility variables directly on the initial accuracy of the remaining sepak takraw game is the influence of other variables apart from the limb flexibility variable. Other variables that may affect the initial accuracy of the sepak takraw game are exercise, biomotor and other physical conditions.

From the results of the description above we can see the results of research on the effect of limb flexibility on the initial accuracy of the game sepaktakraw on Student Education And Training Center Jakarta athletes. This finding shows, that in order to improve the performance of sepak takraw athletes, an athlete must have a good leg shape, of course, where this variable has a direct influence in improving the achievement of Jakarta Student Education And Training Center athletes going forward.

\section{Direct Influence of Body Balance (X3) on Soccer Accuracy on Sepaktakraw (Y)}

There is a significant influence on the balance of the body against the accuracy of the first game of sepak takraw. after testing the hypothesis proved to be individually significant effect on the accuracy of the first football on sepak takraw game at athletes Student Education And Training Center Jakarta. The structural equation of path analysis results from the balance of the body to the initial accuracy of the sepak takraw game is X2 $=0.188 \rho 21+0.982 \varepsilon 1$.

The influence of body balance variables directly on the accuracy of football from the game sepak takraw is $0.1882 \mathrm{x} 100 \%=0.0353$ or $3.53 \%$. From the description can be seen the effect of the body equilibrium variable directly to the accuracy of the beginning of the game sepak takraw the rest is the influence of the variables other than the balance of body variables. Other variables that can 
affect the accuracy of football at the beginning of the game Sepak takraw are exercise, biomotor and other physical and psychological factors.

From the results of the description above we can see the results of research on the effect of the balance of the body on the initial accuracy of the game sepak takraw on Student Education And Training Center Jakarta athletes. These findings show that to improve the performance of athlete sepak takraw, an athlete must have a good body balance of course, where this variable has a direct influence in improving the achievement of Student Education And Training Center athletes in the future.

\section{Direct Influence of Self Confidence (X4) to Accuracy of Football Upper Sepak takraw (Y)}

There is a significant influence of confidence in the accuracy of the early game of sepak takraw. after testing the hypothesis proved to be individually significant effect on the accuracy of the first football on sepak takraw game at athletes Student Education And Training Center DKI Jakarta. The structural equation of path analysis results from self-confidence to the initial accuracy of the sepak takraw game is $\mathrm{X} 2=0.219 \rho 21+0.982 \varepsilon 1$.

The influence of self confidence variable directly to the accuracy of the game on sepak takraw equal to $0.2192 \mathrm{x} 100 \%=0.0438$ or $4.38 \%$. From the affair can be seen the influence of confidence variable directly to the accuracy of the beginning of the game sepak takraw the rest is the influence of the variables other than the variable confidence. Other variables that may affect the initial accuracy of the sepak takraw game are exercise factors, other physical and psychological conditions.

From the results of the description above we can see the results of research on the effect of self-confidence on the accuracy of football at the beginning of the game sepak takraw on Student Education And Training Center DKI Jakarta athletes. These findings indicate that to improve the performance of athlete sepak takraw, an athlete must have good self confidence of course, where this variable has a direct influence in improving the achievement of Student Education And Training Center athletes of DKI Jakarta in the future.

\section{Direct Influence of Coordination of the Feet (X1) on Self-Esteem (X4)}

There is a significant effect of eye-foot coordination on self-confidence in the game sepak takraw. after testing the hypothesis proved that individually significant effect on self confidence in the game sepak takraw in Student Education And Training Center Jakarta athletes. The structural equation of the path analysis of the eye-foot coordination of self-confidence in game sepak takraw is $\mathrm{X} 2=0.178 \rho 21+0.982 \varepsilon 1$.

The influence of eye-foot coordination variables directly on confidence in the game sepak takraw $0.1782 \times 100 \%=0.0356$ or $3.56 \%$. From this description can be seen the effect of eye-foot coordination variables directly to confidence in the game sepak takraw the rest is the influence of the variables other than the variation of eye-foot coordination. Other variables that may affect confidence in the game sepak takraw are exercise, biomotoric and other physical conditions.

From the results of the description above we can see the results of research on the effect of eye-coordinating on self-confidence in the game sepak takraw in Student Education And Training Center DKI Jakarta athletes. This finding shows, that to improve the performance of sepak takraw athletes, an athlete must have good eye-foot coordination of course, where this variable has a direct influence in improving the achievement of Jakarta Student Education And Training Center athletes going forward.

\section{Direct Effect of Limb Formation (X2) on Self Confidence (X4)}

There is a significant influence of limb formation on confidence in the game sepak takraw. after testing the hypothesis proved that individually significant effect on self confidence in the game 
sepak takraw in Student Education And Training Center DKI Jakarta athletes. The structural equation from the results of path analysis from the limb's flexibility to the confidence in the game sepak takraw is $\mathrm{X} 2=0.188 \rho 21+0.982 \varepsilon 1$.

The influence of direct limb flexibility variables on self confidence in the game sepak takraw is $0.1272 \mathrm{x} 100 \%=0.0254$ or $2.54 \%$. From this description can be seen the influence of leg limb variables directly to confidence in game sepak takraw the rest is the influence of other variables other than the leg limb variable. Other variables that may affect confidence in the game sepak takraw are exercise, biomotoric and other physical conditions.

From the results of the description above we can see the results of research on the influence of limb flexibility on self confidence in the game sepak takraw in Student Education And Training Center Jakarta athletes. These findings indicate that to improve the performance of athlete sepak takraw, an athlete must have a good leg limb of course, where this variable has a direct influence in improving the performance of Student Education And Training Center athletes of Jakarta in the future.

\section{Direct Influence Body Balance (X3) to Self Confidence (X4)}

There is a significant influence the body's balance of confidence in the game sepak takraw. after testing the hypothesis proved that individually significant effect on self confidence in the game sepak takraw in Student Education And Training Center Jakarta athletes. The structural equation of path analysis results from the balance of the body to self-confidence in game sepak takraw is $\mathrm{X} 2=$ $0.188 \rho 21+0.982 \varepsilon 1$.

Effect of body equilibrium variable directly to confidence in game sepak takraw equal to $0,1182 \times 100 \%=0,0236$ or $2,36 \%$. From the description can be seen the effect of the body equilibrium variable directly to confidence in the game sepak takraw the rest is the influence of other variables other than the balance of body variables. Other variables that may affect confidence in the game sepak takraw are exercise, biomotoric and other physical conditions.

From the results of the above description we can see the results of research on the effect of body balance on confidence in the game sepak takraw at athletes Student Education And Training Center Jakarta. These findings indicate that to improve the performance of athlete sepak takraw, an athlete must have a good body balance of course, where these variables have a direct influence in improving the performance of Student Education And Training Center athletes in the future of Jakarta.

\section{CONCLUSION}

Based on the results of hypothesis testing, it turns out all hypotheses proposed in significance acceptable. Based on the results of hypothesis testing and research discussion, the following conclusions can be drawn:

1. There is a significant direct effect of eye-foot coordination on the initial accuracy of the game Sepak takraw.

2. There is a significant direct effect of limb flexibility on the initial accuracy of the game Sepak takraw.

3. There is a significant direct effect of the balance of the body on the accuracy of the football over the game sepak takraw.

4. There is a significant direct effect of self-confidence on the accuracy of the first game of sepak takraw.

5. There is a significant direct effect of eye-foot coordination on confidence in the game sepak takraw.

6. There is a significant direct effect of limb formation on confidence in the game sepak takraw. 
7. There is a significant direct effect of the body's balance on self-confidence in the game Sepa ktakraw.

\section{REFERENCE}

Arikunto, Suharsimi. (2006). Research procedure. Jakarta: Rineka Cipta.

Bompa, Tudor O. Peridization. (2009). Theory and Methodology Of Training. Newyork: Human kinetics Rewards.

Carr, Gerry. (2010). Sport Mechanics For Coaches. America: Human Kinetics.

Cholil, Hasanuddin and Nurhasan. (2007). Sports Test and Measurement Module. Bandung: FPOK UPI.

Dawes, Jay and Roozen, Mark. (2011). Developing Agility and Quickness. Champaign: Human Kinetics.

Irianto, Djoko Peluk. (2004). Practical Guidelines for Exercising For Physical Fitness and Health. Yoyakarta: Andi Offset.

Ismaryati. (2011). Sports Tests \& Measurement. Surakarta: UNS Educational Development Institute (LPP) and UNS Publishing and Printing Unit (UNS Press).

Nurhasan. (2007). Test and Sport Measurements. Bandung: FPOK UPI.

Ratamess, Nicholas. (2012). Acsm'c Foundation Of Strength Training and Conditioning. American: Collegen Of Sport Medicine.

Sofyan Hanif, Achmad. (2015). Sepak Takraw Basic Training. Jakarta: PT RajaGrafindo Persada.

Sofyan Hanif, Achmad and Syam, Asry. (2015). Sepak Takraw Pantai. Jakarta: PT RajaGrafindo Persada.

Sugiyono. (2011). Educational Research Methods. Bandung: Alfabeta.

Sukadiyanto and Muluk, Dangsina. (2011). Introduction to Theory and Metedology of Physical Train. Bandung: CV Lubuk Agung.

Tangkudung, James. (2006). Physiology. Jakarta: Smart Jaya.

Tangkudung, James and Puspitorini, Wahyuningtyas. (2012). Sports Coaching "Sports Performance Coaching". Jakarta: Smart Jaya.

Widiastuti. (2011). Tests And Measurements Of Sports. East Jakarta: PT Bumi Timur Jaya.

Zalfendi. (2009). Sepak Takraw Game. Padang: Sukabina Press. 